\title{
Reaction Rate of the Formation of Graft Copolymer by the Coupling Reaction of Polystyryl Anion with Chloromethylated Polystyrene
}

\author{
Koji Ishizu, Takeo Kıto, Takashi Fukuromi, and Toshio KaKurai \\ Department of Polymer Technology, Tokyo Institute of Technology \\ 2-12, Ookayama, Meguro-ku, Tokyo 152, Japan.
}

(Received October 27, 1975)

\begin{abstract}
Chloromethylated polystyrene was reacted with polystyryl anion in tetrahydrofuran (THF) or in mixed solvents of THF $-n$-hexane at $-78^{\circ} \mathrm{C}$. The relative rate constants of the coupling reaction were measured photometrically by carrying out the competitive reactions of the polystyryl anion-chloromethylated polystyrene and the polystyryl anion-triphenylmethyl bromide. By using the analytical method of successive reactions, the relative rate constant of each step-wise process was estimated from the relative rate constant observed. It was found that the rate to form a 1-branched polymer decreased with increasing the degree of polymerization $(D P)$ of polystyryl anion. Moreover, the tendency of the rate to decrease with the progress of the reaction became clearer when the $D P$ of polystyryl anion and the volume fraction of $n$-hexane increased. The factors which influence the formation of the graft copolymer by a coupling reaction are considered in connection with these results.
\end{abstract}

KEY WORDS Chloromethylated Polystyrene / Polystyryl Anion /

Rate Constant / Coupling Reaction / Competitive Reaction / Tri-

phenylmethyl Bromide / Degree of Polymerization /

In a previous paper, ${ }^{1}$ we have reported the phenomena that the reaction ceases to advance when several branches are introduced onto the backbone molecule, in spite of the existence of a sufficient residue of the functional groups (chloromethyl and carbanion). These phenomena could be explained as follows. The pendant groups were hindered by the grafted polymer chain to an appreciable extent and thus the subsequent grafting of the living polymer onto the chloromethyl functions occurred less readily or not at all. Then, to make clear the hindering effects which occur in the formation of the graft copolymer, we have dealt with the kinetic approaches. ${ }^{2}$ Poly(methyl methacrylate)(PMMA) was reacted with polystyryl anion in mixed solvents of THFmethylcyclohexane at $-78^{\circ} \mathrm{C}$. The changes in the concentration of the living ends with the reaction time were measured photometrically. By using the analytical method of successive reactions, the rate constant of each step-wise process $\left(k_{0}, k_{1}, \cdots, k_{j}, \cdots, k_{n}\right)$, where $k_{j}$ means the rate constant to form the $j$-th branched graft copolymer from the $(j-1)$-th branched graft copolymer, was estimated from the rate constant observed $\left(k_{\text {obsd }}\right)$. It was found that $k_{n}$ decreased rapidly with increasing number of polystyrene branches on the PMMA molecule. The tendency of the rate constant to decrease with the progress of the reaction became clearer when the volume fraction of methylcyclohexane increased.

The details of the rate of reaction of polystyryl anions with chloromethylated polystyrene at low temperatures have not been published. In this paper we report the relative rate constants of the coupling reaction which were measured photometrically by carrying out the competitive reactions of the polystyryl anion-chloromethylated polystyrene and the polystyryl anion-triphenyl methyl bromide. The relative rate constant of each step-wise process was obtained from the same method as in the previous report. ${ }^{2}$

\section{EXPERIMENTAL}

Altares, et al., ${ }^{3}$ and Pannell ${ }^{4}$ have reported the 
Table I. Characterization of chloromethylated polystyrene

\begin{tabular}{ccc}
\hline & $D P^{\mathrm{a}}$ & $\begin{array}{c}\text { Chloromethyl groups } \\
\text { (number per backbone } \\
\text { polymer molecule) }\end{array}$ \\
\hline BP-1 & 154 & 39
\end{tabular}

a Calculated by viscometric measurement of polystyrene before chloromethylation.

b Calculated by using Volhard's method.

reaction of living polymer with chloromethylated polystyrene, and have obtained comb-shaped polymers.

The chloromethylation of polystyrene has been studied previously. ${ }^{5}$ It was possible to introduce different amounts of the chloromethyl group in a controlled manner for the reaction. The polystyrene was chloromethylated with chloromethyl methyl ether using stannic chloride as a catalyst. The parent polymer was prepared by polymerization of styrene monomer with $n$-butyllithium ( $n$-BuLi) in THF at $-78^{\circ} \mathrm{C}$. The determination of the chlorine content was carried out by Volhard's method. ${ }^{6}$ The results of the characterization of the backbone polymer are shown in Table $\mathrm{I}$.

Polystyryl anion was prepared by polymerization of styrene monomer with $n$-BuLi in THF at $-78^{\circ} \mathrm{C}$. The molecular weight of polystyrene was determined from viscometric measurements by using the following equation: ${ }^{7}$

$$
M_{w}=1.7 \times 10^{5}[\eta]^{1.37} \text { in toluene at } 30^{\circ} \mathrm{C}
$$

The determination of the concentration of living ends was carried out by Volhard's method. ${ }^{6}$ That is to say, polystyryl anion was reacted with a large excess of $n$-butyl bromide in THF. The LiBr salts produced were titrated by using Volhard's method.

The changes in the concentration of the living ends with the reaction time, can be observed photometrically at the characteristic absorption in $\mathrm{THF}\left(\lambda_{\max }=338 \mathrm{~nm}, \log \varepsilon=4.00\right){ }^{8}$ However, the usual cell could not be used in this reaction, because of the frost which covered one part of the cell at low temperatures. Therefore our investigation was carried out with the competitive reactions of $(\mathrm{A})$ and $(\mathrm{B})$ at $-78^{\circ} \mathrm{C}$, i.e., reaction $(\mathrm{A})$ : polystyryl anion-chloromethylated polystyrene; reaction (B): polystyryl anion-triphenylmethyl bromide. The solution of living polymer was introduced into the solutions which contained both triphenylmethyl bromide and chloromethylated polystyrene with vigorous stirring. After the specific color of living polymer disappeared, the reaction system was allowed to warm up to room temperature and the concentration of triphenylmethyl radical formed by the reaction $(B)^{9}$ was measured photometrically.

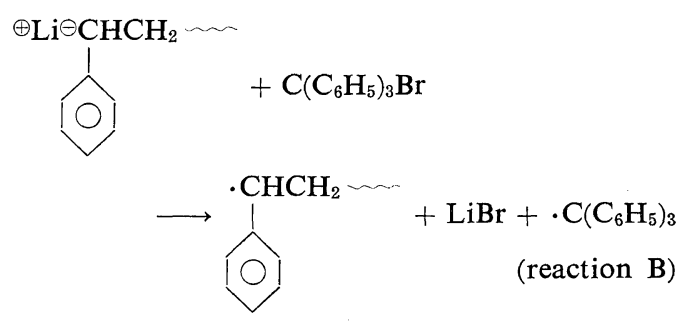

Triphenylmethyl radical is in equilibrium with hexaphenylethane in the solutions, ${ }^{10}$ so the relation between (concentration of triphenylmethyl

$$
2 \cdot \mathrm{C}\left(\mathrm{C}_{6} \mathrm{H}_{5}\right)_{3} \rightleftarrows \mathrm{C}_{2}\left(\mathrm{C}_{6} \mathrm{H}_{5}\right)_{6}
$$

radical) plus 2 (concentration of hexaphenyl ethane) and the optical density at $514 \mathrm{~nm}$ (specific absorption maximum of triphenylmethyl radical in THF) was determined first. The details of the experiment are explained in the following paragraphs.

\section{Calibration Curve}

The relation between the optical density $(O D)$ at $514 \mathrm{~nm}$ and the concentration of (triphenyl-

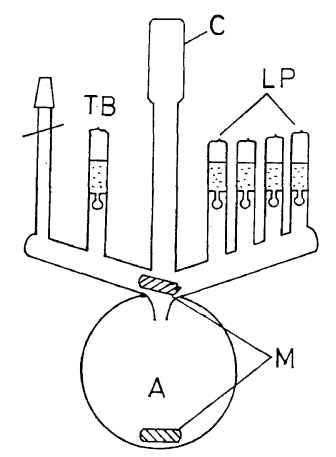

Figure 1. Reaction apparatus to measure the change of the concentration of triphenyl methyl radical: LP, solution of polystyryl anion: TB, solution of triphenyl methyl bromide; $\mathrm{C}$, quartz cell; M, magnet coated with glass. 


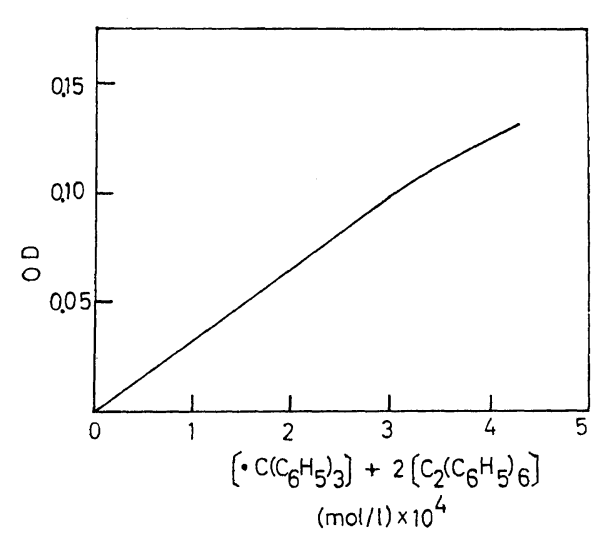

Figure 2. Relationship between optical density and concentration of $\left(\left[\cdot \mathrm{C}\left(\mathrm{C}_{6} \mathrm{H}_{5}\right)_{3}\right]+2\left[\mathrm{C}_{2}\left(\mathrm{C}_{6} \mathrm{H}_{5}\right)_{6}\right]\right)$.

methyl radical) plus the concentration of 2 (hexaphenyl ethane) was determined by using the apparatus shown in Figure 1. The solution of triphenyl methyl bromide was introduced into the reaction vessel (A). An ampoule of living polymer was broken, and the $O D$ was measured by a HITACHI 124 Spectrophotometer after $2 \mathrm{hr}$. The same operations were repeated many times changing the concentration and the $D P$ of living polymer, and the concentration of triphenyl methyl bromide. The results obtained did not depend upon these reaction conditions, but only upon the value of $[\mathrm{L}] v /(v+V)$, where $[\mathrm{L}]$ is the concentration of living polymer in an ampoule, $v$ is the volume of living polymer solution, and $V$ is the volume of the solution in part A. The result is shown in Figure 2.

\section{Competitive Reaction and Analysis of Data}

The reaction was carried out with the apparatus similar to that shown in Figure 1. The different points were: (1) the concentration and the $D P$ of living polymer in each ampoule were the same; and (2) chloromethylated polystyrene was contained in the solution of part A.

$k_{\mathrm{A}}$ is defined as the rate constant of reaction (A) and $k_{\mathrm{B}}$ as that of reaction (B). Assuming that reactions (A) and (B) proceed as secondorder reactions, the relation of the competitive reactions can be written as follows:

$$
\ln \left(1-\frac{\Delta C_{\mathrm{A}}}{\left(C_{\mathrm{A}}\right)_{0}}\right)=\frac{k_{\mathrm{A}}}{k_{\mathrm{B}}} \ln \left(1-\frac{\Delta C_{\mathrm{B}}}{\left(C_{\mathrm{B}}\right)_{0}}\right)
$$

In the case of $\Delta C_{\mathrm{A}} \ll\left(C_{\mathrm{A}}\right)_{0}$ and $\Delta C_{\mathrm{B}} \ll\left(C_{\mathrm{B}}\right)_{0}$ where

$$
\frac{\Delta C_{\mathrm{A}}}{\left(C_{\mathrm{A}}\right)_{0}}=\frac{k_{\mathrm{A}}}{k_{\mathrm{B}}} \cdot \frac{\Delta C_{\mathrm{B}}}{\left(C_{\mathrm{B}}\right)_{0}}
$$

$\Delta C_{\mathrm{A}}$ : the concentration of chloromethyl groups reacted with polystyryl anion.

$\Delta C_{\mathrm{B}}$ : the concentration of triphenylmethyl bromide reacted with polystyryl anion.

$\left(C_{\mathrm{A}}\right)_{0}$ : the initial concentration of chloromethyl groups at each reaction cycle.

$\left(C_{\mathrm{B}}\right)_{0}$ : the initial concentration of triphenylmethyl bromide at each reaction cycle.

The average number of branches per one backbone polymer molecule could be calculated as follows:

$$
\text { Number of Branches }=\Delta C_{\mathrm{A}} / C_{\mathrm{p}}
$$

where $C_{\mathrm{p}}$ is the concentration of chloromethylated polystyrene.

\section{Determination of $k_{\mathrm{B}}$}

If $k_{\mathrm{B}}$ could be determined, $k_{\mathrm{A}}$ could be calculated from eq 1 or eq 2 . But this reaction (living polymer-triphenylmethyl bromide) was very rapid, and we could not measure directly the value of $k_{\mathrm{B}}$. Then the absolute value of $k_{\mathrm{E}}$ (the rate constant of the reaction between polystyryl anion and methyl isobutyrate) was meas-

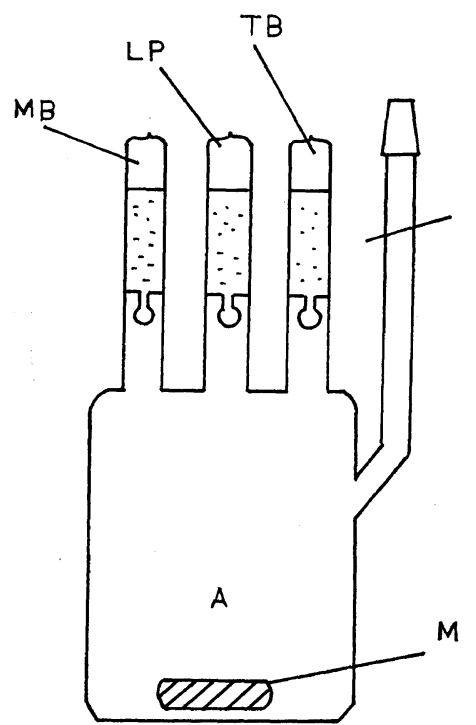

Figure 3. Apparatus to measure $k_{\mathrm{E}}$ : LP, solution of polystyryl anion; MB, solution of methyl isobutyrate; TB, $n$-butyl bromide; M, magnet coated with glass. 
ured, and the competitive reactions of polystyryl anion-methyl isobutyrate and polystyryl aniontriphenylmethyl bromide were carried out. Therefore $k_{\mathrm{B}}$ was estimated by using the same method as the estimation of $\left(k_{\mathrm{A}}\right)_{i} / k_{\mathrm{B}}$. The procedure used to measure $k_{\mathrm{E}}$ was as follows. The entire apparatus shown in Figure 3 was cooled to $-78^{\circ} \mathrm{C}$ after the sealing off under high vacuum and the introduction of methyl isobutyrate to part A. After cooling for $2 \mathrm{hr}$, the solution of living polymer was introduced to part $A$ as quickly as possible. After the reaction system was maintained for the fixed time, the unreacted living ends were deactivated with $n$-butyl bromide and this concentration was measured by Volhard's method. The apparent second-order rate constant could be calculated by using the values of the initial concentrations of living ends and of methyl isobutylate, the concentration of living ends deactivated with $n$-butyl bromide, and the reaction time. The same procedures were repeated several times, and the obtained values of $k_{\mathrm{E}}$ were averaged.

\section{Estimation of $k_{n}$}

The general scheme of grafting by coupling reaction with respect to one backbone molecule can be written as follows:

$$
\begin{aligned}
\mathrm{G}_{0} \underset{k_{0}}{\longrightarrow} \mathrm{G}_{1} \underset{k_{1}}{\longrightarrow} \mathrm{G}_{2} \underset{k_{2}}{\longrightarrow} \cdots \mathrm{G}_{j} \\
\underset{{ }_{j}}{\longrightarrow} \cdots \mathrm{G}_{n-1} \underset{k_{n-1}}{\longrightarrow} \mathrm{G}_{n}
\end{aligned}
$$

where

$$
\begin{aligned}
\mathrm{G}_{0}: & \text { backbone polymer with no branch } \\
\mathrm{G}_{1}: & 1 \text {-branched graft copolymer } \\
& +\ldots \\
\mathrm{G}_{n}: & n \text {-branched graft copolymer } \\
k_{j}: & \text { rate constant to form the } j \text {-th branched } \\
& \text { graft copolymer from the }(j-1) \text {-th branched } \\
& \text { graft copolymer }
\end{aligned}
$$

In the actual case of the reaction system, there exist not only $\mathrm{G}_{0}$ but also $\mathrm{G}_{1}, \mathrm{G}_{2}, \mathrm{G}_{3}, \ldots$. Then the rate constant observed $\left(k_{\text {obsd }}\right)$ can be defined from the following equation:

$$
k_{\mathrm{obsd}}=\frac{\sum_{j=0}^{\infty} k_{j}\left[\mathrm{G}_{j}\right]}{\left[\mathrm{G}_{0}\right]_{0}}
$$

where $\left[\mathrm{G}_{j}\right]$ means the molar concentration of $j$ branched graft copolymer in the reaction system.
The estimation method for $k_{n}$ was described in detail in a previous report. ${ }^{2}$

\section{Recognition of Graft Copolymer}

In order to recognize the formation of graft copolymer, the turbidimetric measurement of the product was carried out at $300-400 \mathrm{~nm}$ (good solvent, methyl ethyl ketone; non solvent, isopropyl alcohol; temperature, $20^{\circ} \mathrm{C}$ ).

\section{RESULTS AND DISCUSSION}

In order to know whether the polystyryl anions coupled to form a graft copolymer or not, the turbidimetric measurement of the product was carried out. As shown in Figure 4, there is no appearance of any turbidity caused by the raw living polystyrene. Then we may conclude that the living polymer molecules reacted with the backbone polymer are completely fixed on the chains.

Table II shows the reaction conditions and the observed values of $k_{\mathrm{E}}$. The variation of $k_{\mathrm{E}}$

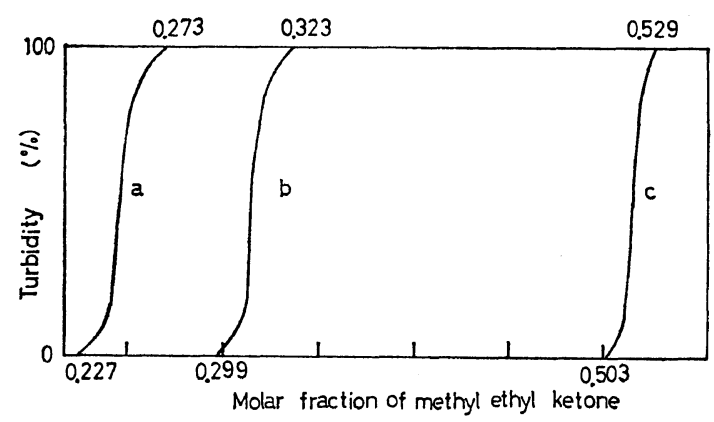

Figure 4. Turbidimetric titration in methyl ethyl ketone-isopropyl alcohol system: a, product; b, polystyrene; c, chloromethylated polystyrene.

Table II. Reaction conditions and results of the reactions between polystyryl anion and methyl isobutyrate

\begin{tabular}{ccccc}
\hline Run & $\begin{array}{c}\text { Range of concn } \\
\text { of deactivated } \\
\text { polystyryl anion, } \\
\text { mol } / l\end{array}$ & $\begin{array}{c}\text { Methyl } \\
\text { isobutyrate } \\
\text { concn, } \\
\text { mol } / l\end{array}$ & $\begin{array}{c}\text { Reac- } \\
\text { tion } \\
\text { time, } \\
\text { sec }\end{array}$ & $\begin{array}{c}k_{\mathrm{E}}, \\
\mathrm{moc}^{-1}\end{array}$ \\
\hline L-1 & $6.21 \sim 2.70 \times 10^{-4}$ & $110.5 \times 10^{-4}$ & 511 & 0.151 \\
L-2 & $8.31 \sim 5.76 \times 10^{-4}$ & $82.3 \times 10^{-4}$ & 256 & 0.178 \\
L-3 & $11.6 \sim 7.92 \times 10^{-4}$ & $122.1 \times 10^{-4}$ & 373 & 0.085 \\
\hline
\end{tabular}

a Solvent, THF; reaction temp, $-78^{\circ} \mathrm{C}$.

b $D P, 98$. 


\section{K. Ishizu, T. Kito, T. Fukutomi, and T. Kakurai}

Table III. Reaction conditions and results of the competitive reactions of the polystyryl aniontriphenylmethyl bromide and the polystyryl anion-methyl isobutyrate

\begin{tabular}{lcccc}
\hline Run & $\begin{array}{c}\text { Polystyryl } \\
\text { anion }^{\mathrm{b}} \\
\text { concn, } \\
\text { mol } / l\end{array}$ & $\begin{array}{c}\text { Triphenyl- } \\
\text { methyl } \\
\text { bromide } \\
\text { concn, } \\
\text { mol/l }\end{array}$ & $\begin{array}{c}\text { Methyl } \\
\text { isobutyrate } \\
\text { concn, } \\
\text { mol } / l\end{array}$ & $k_{\mathrm{B}} / k_{\mathrm{E}}$ \\
\hline $\mathrm{R}-1$ & $1.5 \times 10^{-4}$ & $2.50 \times 10^{-2}$ & $5.89 \times 10^{-3}$ & 224 \\
$\mathrm{R}-2$ & $1.5 \times 10^{-4}$ & $2.50 \times 10^{-2}$ & $6.56 \times 10^{-3}$ & 234 \\
$\mathrm{R}-3$ & $1.5 \times 10^{-4}$ & $2.50 \times 10^{-2}$ & $6.85 \times 10^{-3}$ & 229 \\
\hline
\end{tabular}

a Solvent, THF; reaction temp, $-78^{\circ} \mathrm{C}$.

b $D P, 98$.

Table IV. Reaction conditions of the competitive reactions of the polystyryl anion-chloromethylated polystyrene and the polystyryl anion-triphenylmethyl bromide: $\mathrm{P}-1, \mathrm{P}-2$, and $\mathrm{P}-3^{\mathrm{a}}$

\begin{tabular}{|c|c|c|c|c|}
\hline \multirow[b]{2}{*}{ Run } & \multicolumn{2}{|c|}{ Polystyryl anion } & \multirow{2}{*}{$\begin{array}{l}\text { Backbone } \\
\text { polymer }^{\mathrm{b}} \\
\text { concn, } \\
\mathrm{mol} / l\end{array}$} & \multirow{2}{*}{$\begin{array}{l}\text { Triphenylmethyl } \\
\text { bromide concn, } \\
\text { mol/l }\end{array}$} \\
\hline & $\begin{array}{c}\text { concn, } \\
\mathrm{mol} / l\end{array}$ & $D P$ & & \\
\hline P-1 & $1.5 \times 10^{-}$ & 98 & 0 & \\
\hline $\mathbf{P}-2$ & $1.5 \times 10^{-4}$ & 152 & $6.92 \times 10^{-3}$ & $3.00 \times 10^{-2}$ \\
\hline $\mathbf{P}-3$ & $1.5 \times 10^{-4}$ & 340 & $8.47 \times 10^{-3}$ & $3.00 \times 10^{-2}$ \\
\hline
\end{tabular}

a Solvent, THF; reaction temp, $-78^{\circ} \mathrm{C}$.

b $D P, 154$; chloromethyl groups, 39 (number per backbone polymer molecule).

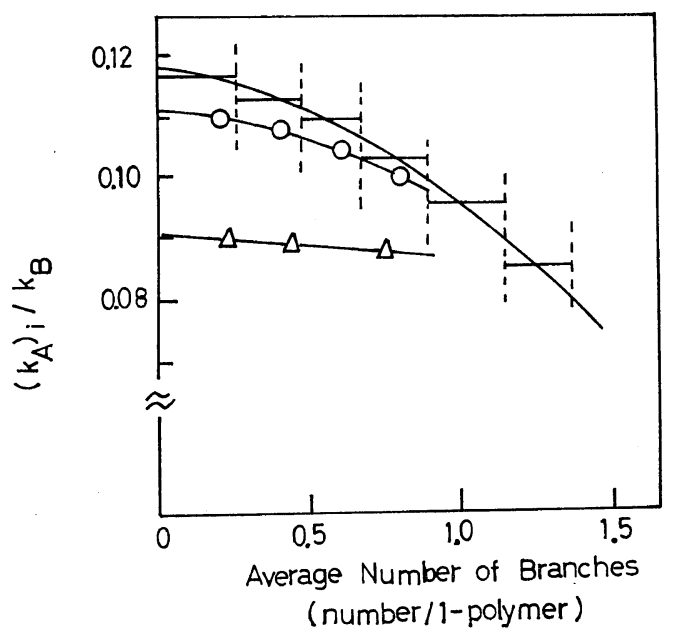

Figure 5a. Relationship between $\left(k_{\mathrm{A}}\right)_{i} / k_{\mathrm{B}}(i=0,1$, and 2) and average number of branches $(\mathbf{P}-1)$ : $\longrightarrow,\left(k_{\mathrm{A}}\right)_{\mathrm{obsd}} / k_{\mathrm{B}} ;-\bigcirc-,\left(k_{\mathrm{A}}\right)_{1} / k_{\mathrm{B}} ;-\triangle-,\left(k_{\mathrm{A}}\right)_{2} / k_{\mathrm{B}}$. with the variation of the concentration of living polymer is not so large. Moreover in this study, the reaction was carried out under the same initial concentration of living polymer. So the major part of the living polymer reacted with backbone polymer with almost the same reactivity. Considering the reaction conditions, it is suitable to use the values of $0.1-0.2 \mathrm{lmol}^{-1} \mathrm{sec}^{-1}$ for $k_{\mathrm{E}}$, when it is necessary to determine the absolute values of $k_{\mathrm{A}}$ and $k_{\mathrm{B}}$. Table III shows the reaction conditions and results of the competitive reactions of the polystyryl anion-triphenylmethyl bromide and the polystyryl anion-

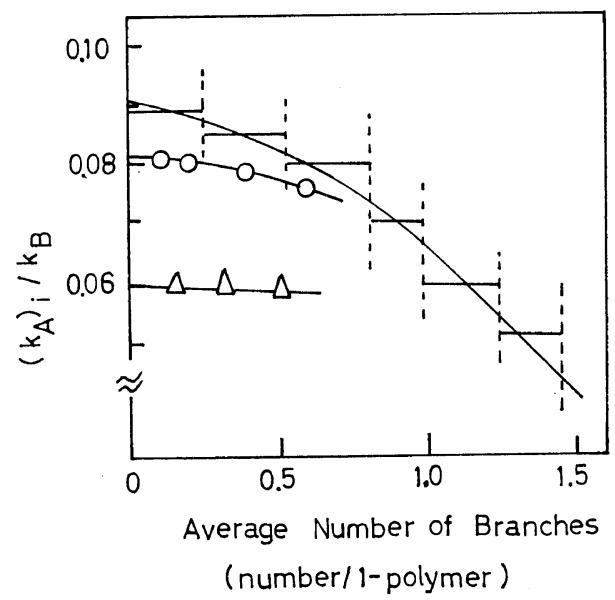

Figure 5b. Relationship between $\left(k_{\mathrm{A}}\right)_{i} / k_{\mathrm{B}}(i=0,1$, and 2) and average number of branches (P-2); ,$-\left(k_{\mathrm{A}}\right)_{\mathrm{obsd}} / k_{\mathrm{B}} ;-\bigcirc-,\left(k_{\mathrm{A}}\right)_{1} / k_{\mathrm{B}} ;-\triangle-,\left(k_{\mathrm{A}}\right)_{2} / k_{\mathrm{B}}$.

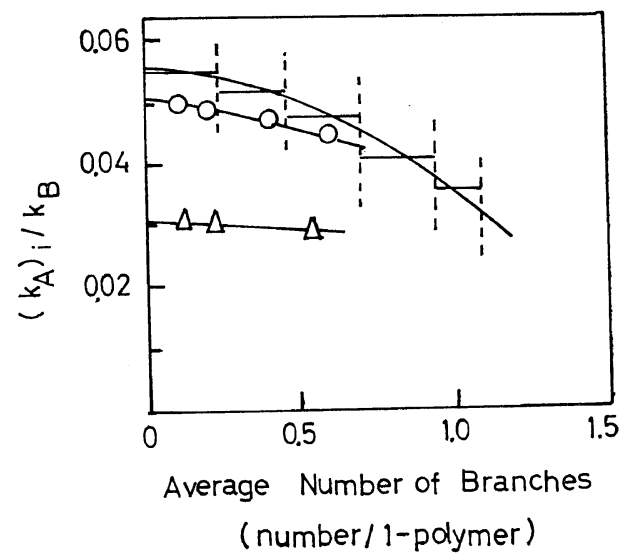

Figure 5c. Relationship between $\left(k_{\mathrm{A}}\right)_{i} / k_{\mathrm{B}}(i=0,1$, and 2) and average number of branches (P-3): $\longrightarrow,\left(k_{\mathrm{A}}\right)_{\mathrm{obsd}} / k_{\mathrm{B}} ;-\bigcirc-,\left(k_{\mathrm{A}}\right)_{1} / k_{\mathrm{B}} ;-\triangle-,\left(k_{\mathrm{A}}\right)_{2} / k_{\mathrm{B}}$. 
methyl isobutyrate. $k_{\mathrm{B}} / k_{\mathrm{E}}$ calculated from the results of the competitive reactions is about 230 . Then $k_{\mathrm{B}}$ becomes $32 \mathrm{lmol}^{-1} \mathrm{sec}^{-1}$ (assuming $k_{\mathrm{E}}=$ $0.14 \mathrm{lmol}^{-1} \mathrm{sec}^{-1}$ ).

Table IV shows the conditions of the reactions of polystyryl anion with chloromethylated polystyrene in THF, varying the $D P$ of polystyryl anion $(\mathbf{P}-1, \mathbf{P}-2$, and $\mathbf{P}-3)$. In Figures $5 \mathrm{a}, 5 \mathrm{~b}$, and $5 \mathrm{c},\left(k_{\mathrm{A}}\right)_{i} / k_{\mathrm{B}}(i=0,1$, and 2$)$ are plotted against the average number of branches on a backbone polymer molecule for $\mathrm{P}-1, \mathrm{P}-2$, and $\mathrm{P}-3$ respectively. The relative rate constants obtained are summarized in Table V. First of all, we consider the effects of the $D P$ of polystyryl anion on $\left(k_{\mathrm{A}}\right)_{0} / k_{\mathrm{B}}$. The results obtained in Table $\mathrm{V}$ are plotted in Figure 6. It is apparent from this figure that $\left(k_{\mathrm{A}}\right)_{0} / k_{\mathrm{B}}$ decreased with increasing the $D P$ of polystyryl anion. In a previous study, ${ }^{11}$ the formation of 1:1-graft copolymer (a backbone having a single branched chain) by a coupling reaction depended strongly on the intermolecular excluded volume. Therefore the phenomenon obtained in this investigation can be also explained from the fact that the effect of the intermolecular excluded volume increased with increasing the $D P$ of polystyryl anion. In order to investigate the effects of the $D P$ of the intro-

Table V. Relative rate constants of the competitive reactions of the polystyryl anion-chloromethylated polystyrene and the polystyryl aniontriphenylmethyl bromide: $\mathbf{P}-1, \mathbf{P}-2$, and $\mathbf{P}-3$

\begin{tabular}{cccc}
\hline Run & $\left(k_{\mathrm{A}}\right)_{0} / k_{\mathrm{B}}$ & $\left(k_{\mathrm{A}}\right)_{1} / k_{\mathrm{B}}$ & $\left(k_{\mathrm{A}}\right)_{2} / k_{\mathrm{B}}$ \\
\hline $\mathrm{P}-1$ & 0.118 & 0.111 & 0.091 \\
$\mathrm{P}-2$ & 0.091 & 0.081 & 0.060 \\
$\mathrm{P}-3$ & 0.055 & 0.049 & 0.030 \\
\hline
\end{tabular}

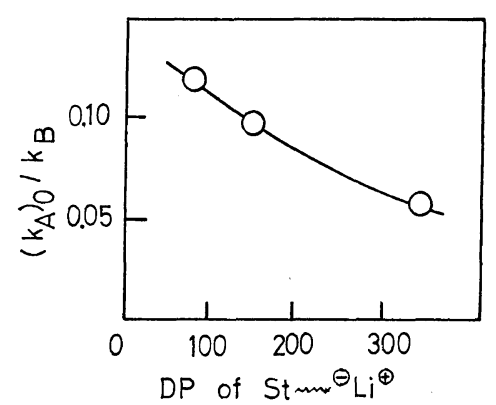

Figure 6. Relationship between $\left(k_{\mathrm{A}}\right)_{0} / k_{\mathrm{B}}$ and $D P$ of polystyryl anion for $\mathrm{P}-1, \mathrm{P}-2$, and $\mathrm{P}-3$.

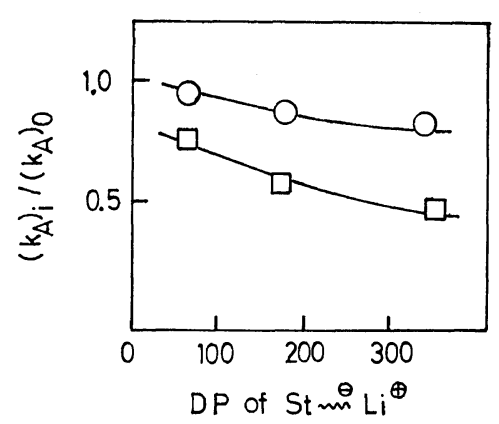

Figure 7. Relationships between $\left(k_{\mathrm{A}}\right)_{i} /\left(k_{\mathrm{A}}\right)_{0}(i=1$ and 2) and $D P$ of polystyryl anion for $\mathrm{P}-1, \mathrm{P}-2$, and P-3: $\bigcirc,\left(k_{\mathrm{A}}\right)_{1} /\left(k_{\mathrm{A}}\right)_{0} ; \square,\left(k_{\mathrm{A}}\right)_{2} /\left(k_{\mathrm{A}}\right)_{0}$.

duced branches on $\left(k_{\mathrm{A}}\right)_{i} / k_{\mathrm{B}}(i=1$ and 2$)$, the degree of drop of $\left(k_{\mathrm{A}}\right)_{i}$ against $\left(k_{\mathrm{A}}\right)_{0}$ is calculated. Figure 7 shows the relationship between $\left(k_{\mathrm{A}}\right)_{i} /\left(k_{\mathrm{A}}\right)_{0}$ (i=1 and 2 ) and the $D P$ of polystyryl anion. The values of both $\left(k_{\mathrm{A}}\right)_{1} /\left(k_{\mathrm{A}}\right)_{0}$ and $\left(k_{\mathrm{A}}\right)_{2} /\left(k_{\mathrm{A}}\right)_{0}$ decrease with increasing the $D P$ of polystyryl anion. And it is found that $\left(k_{\mathrm{A}}\right)_{i}$ decreases rapidly with increasing number of polystyrene branches on the backbone molecule. Thus, the segment density around the functional groups of a backbone polymer molecule is considered to increase with increasing the $D P$ and the number of polystyrene branches.

Chloromethylated polystyrene was also reacted with polystyryl anion in $\mathrm{THF}-n$-hexane mixtures, under the reaction conditions shown in Table VI. In Figures $8 \mathrm{a}$ and $8 \mathrm{~b},\left(k_{\mathrm{A}}\right)_{i} / k_{\mathbf{B}}(i=0,1$, and 2$)$ are plotted against the average number of branches on a backbone polymer molecule for $\mathrm{P}-4$ and P-5 respectively. The DP of polystyryl anion

Table VI. Reaction conditions of the competitive reactions of the polystyryl anion-chloromethylated polystyrene and the polystyryl anion-triphenyl methyl bromide: P-4 and P-5a

\begin{tabular}{lcccc}
\hline Run & $\begin{array}{c}\text { Polystyryl } \\
\text { anion }^{\mathrm{b}} \\
\text { concn, } \\
\mathrm{mol} / \mathrm{l}\end{array}$ & $\begin{array}{c}\text { Backbone } \\
\text { polymer }^{\mathrm{c}} \\
\text { concn, } \\
\mathrm{mol} / l\end{array}$ & $\begin{array}{c}\text { Triphenyl- } \\
\text { methyl } \\
\text { bromide } \\
\text { concn, } \\
\mathrm{mol} / l\end{array}$ & $\begin{array}{c}n \text {-hexane, } \\
\text { vol } \%\end{array}$ \\
\hline $\mathrm{P}-4$ & $1.5 \times 10^{-4}$ & $6.59 \times 10^{-3}$ & $3.00 \times 10^{-2}$ & 15 \\
$\mathrm{P}-5$ & $1.5 \times 10^{-4}$ & $7.57 \times 10^{-3}$ & $3.00 \times 10^{-2}$ & 32 \\
\hline
\end{tabular}

a Solvent, THF- $n$-hexane; reaction temp, $-78^{\circ} \mathrm{C}$. b $D P, 152$.

c DP, 154; chloromethyl groups, 39 (number per backbone polymer molecule). 


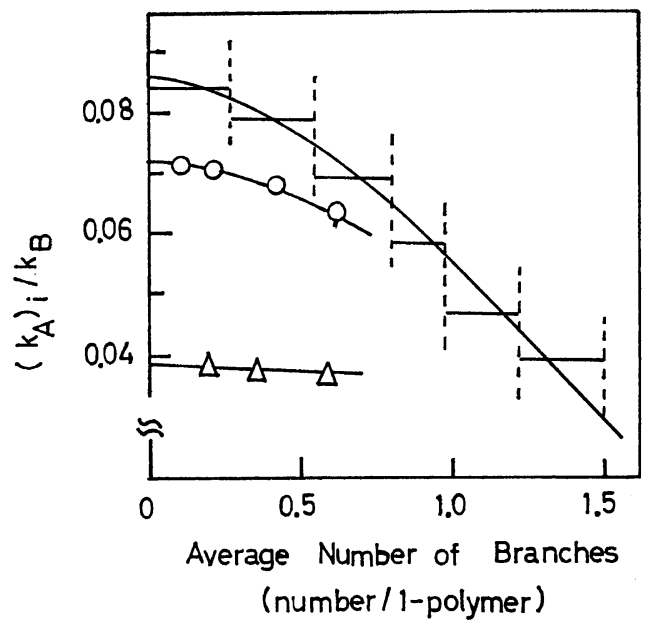

Figure 8a. Relationship between $\left(k_{\mathrm{A}}\right)_{i} / k_{\mathrm{B}}(i=0,1$, and 2) and average number of branches (P-4): ,$-\left(k_{\mathrm{A}}\right)_{\text {obsd }} / k_{\mathrm{B}} ;-\bigcirc-,\left(k_{\mathrm{A}}\right)_{1} / k_{\mathrm{B}} ;-\triangle-,\left(k_{\mathrm{A}}\right)_{2} / k_{\mathrm{B}}$.

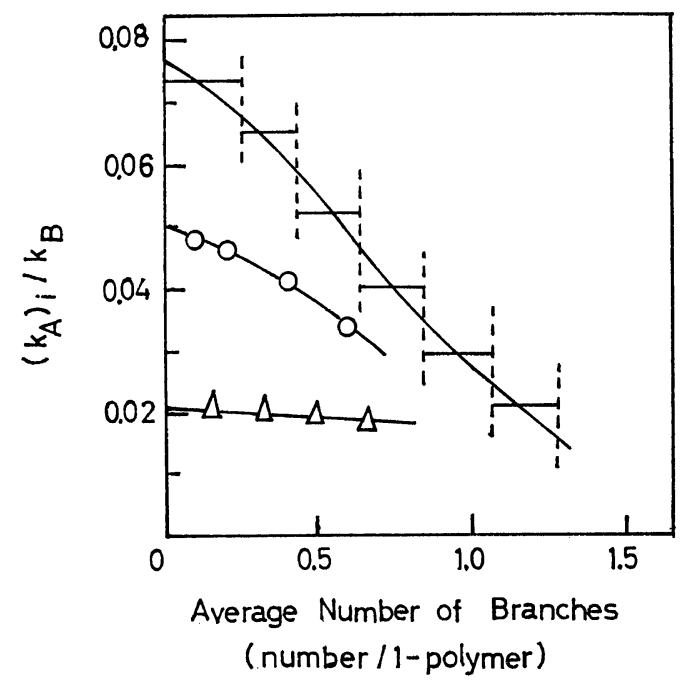

Figure 8b. Relationship between $\left(k_{\mathrm{A}}\right)_{i} / k_{\mathrm{B}}(i=0,1$, and 2) and average number of branches (P-5): ,$-\left(k_{\mathrm{A}}\right)_{\mathrm{obsd}} / k_{\mathrm{B}} ;-\bigcirc-,\left(k_{\mathrm{A}}\right)_{1} / k_{\mathrm{B}} ;-\triangle-,\left(k_{\mathrm{A}}\right)_{2} / k_{\mathrm{B}}$.

used in reaction $\mathrm{P}-2, \mathrm{P}-4$, and $\mathrm{P}-5$ was constant. Then the relative rate constants obtained in these reactions are summarized in Table VII. In $\mathbf{P}-2$, $\left(k_{\mathrm{A}}\right)_{1} / k_{\mathrm{B}}$ decreased very little in comparison with $\left(k_{\mathrm{A}}\right)_{0} / k_{\mathrm{B}}$, and $\left(k_{\mathrm{A}}\right)_{2} / k_{\mathrm{B}}$ decreased rapidly in comparison with $\left(k_{\mathrm{A}}\right)_{0} / k_{\mathrm{B}}$; the results of $\mathrm{P}-4$ and $\mathrm{P}-5$ showed this tendency more clearly $\left(\left(k_{\mathrm{A}}\right)_{i} / k_{\mathrm{B}}\right.$ decreased rapidly with increasing the volume fraction of the poor solvent $n$-hexane). These results
Table VII. Relative rate constants of the competitive reactions of the polystyryl anion-chloromethylated polystyrene and the polystyryl anion -triphenylmethyl bromide: $\mathbf{P}-2, \mathbf{P}-4$, and $\mathrm{P}-5^{\mathrm{a}}$

\begin{tabular}{cccc}
\hline Run & $\left(k_{\mathrm{A}}\right)_{0} / k_{\mathrm{B}}$ & $\left(k_{\mathrm{A}}\right)_{1} / k_{\mathrm{B}}$ & $\left(k_{\mathrm{A}}\right)_{2} / k_{\mathrm{B}}$ \\
\hline P-2 & 0.091 & 0.081 & 0.060 \\
P-4 & 0.086 & 0.072 & 0.039 \\
P-5 & 0.077 & 0.048 & 0.020 \\
\hline
\end{tabular}

a $n$-hexane volume (\%): P-2, $0 ; \mathrm{P}-4,15 ; \mathrm{P}-5,32$.

were similar to those obtained ${ }^{2}$ in the coupling reactions of polystyryl anion with PMMA. The decay of $\left(k_{\mathrm{A}}\right)_{i} / k_{\mathrm{B}}$, i.e., the progressively decreasing rate constant of the addition, $k_{0}, k_{1}, k_{2}, \cdots$ with increasing number of polystyrene branches on the chloromethylated polystyrene molecule, is considered to correspond to the hindering effects of the branches around the functional groups on a backbone molecule.

The values of the absolute rate constants of the couplings between chloromethylated polystyrene and polystyryl anion at $-78^{\circ} \mathrm{C}$ were $3.8\left(\mathbf{P}-1:\left(k_{\mathrm{A}}\right)_{0}\right)-0.6\left(\mathbf{P}-5:\left(k_{\mathrm{A}}\right)_{2}\right) l \mathrm{~mol}^{-1} \mathrm{sec}^{-1}$, and depended strongly on the $D P$ of polystyryl anion and the number of polystyrene branches on the backbone molecule.

\section{REFERENCES}

1. K. Ishizu, T. Fukutomi, and T. Kakurai, Polymer J., 7, 228 (1975).

2. K. Ishizu, T. Fukutomi, and T. Kakurai, ibid., 7, 438 (1975).

3. T. Altares, Jr., D. P. Wyman, and V. R. Allen, J. Polym. Sci. Part A, 3, 4131 (1965).

4. J. Pannell, Polymer, 12, 558 (1971).

5. G. D. Jones, Ind. Eng. Chem., 44, 2686 (1952).

6. G. Iwasaki, "Bunseki Kagaku Gaisetsu (Introduction to Quantitative Analysis)", Gakujutsutosho, Tokyo, 1963, p 276.

7. T. Fujimoto, N. Ozaki, and M. Nagasawa, J. Polym. Sci. Part A, 3, 2259 (1965).

8. R. Asami, M. Levy, and M. Szwarc, J. Chem. Soc., 361 (1962).

9. D. H. Lichards, Chemical Comm., 322 (1968).

10. H. Lankamp, W. T. Nauta, and C. MacLean, Tetrahedron Lett., 249 (1968).

11. K. Ishizu, T. Fukutomi, and T. Kakurai, Polymer J., 7, 570 (1975). 